\title{
Cytokines Induced by Edwardsiella tarda: Profile and Role in Antibacterial Immunity
}

\author{
Huili Li ${ }^{1,2,3}$, Boguang Sun ${ }^{1,2}$, Shuai Jiang ${ }^{1,2}$ and Li Sun 1,2,3,* \\ 1 CAS Key Laboratory of Experimental Marine Biology, Institute of Oceanology, Center for Ocean \\ Mega-Science, Chinese Academy of Sciences, Qingdao 266071, China; lihuili@qdio.ac.cn (H.L.); \\ sunboguang@qdio.ac.cn (B.S.); sjiang@qdio.ac.cn (S.J.) \\ 2 Laboratory for Marine Biology and Biotechnology, Pilot National Laboratory for Marine Science and \\ Technology (Qingdao), Qingdao 266237, China \\ 3 College of Earth and Planetary Sciences, University of Chinese Academy of Sciences, Beijing 100049, China \\ * Correspondence: 1sun@qdio.ac.cn
}

Citation: Li, H.; Sun, B.; Jiang, S.; Sun, L. Cytokines Induced by Edwardsiella tarda: Profile and Role in Antibacterial Immunity. Biomolecules 2021, 11, 1242. https://doi.org/ 10.3390/biom11081242

Academic Editor: Piotr Ceranowicz

Received: 19 June 2021

Accepted: 16 August 2021

Published: 19 August 2021

Publisher's Note: MDPI stays neutral with regard to jurisdictional claims in published maps and institutional affiliations.

Copyright: () 2021 by the authors. Licensee MDPI, Basel, Switzerland. This article is an open access article distributed under the terms and conditions of the Creative Commons Attribution (CC BY) license (https:// creativecommons.org/licenses/by/ $4.0 /)$.

\begin{abstract}
Edwardsiella tarda is a Gram-negative bacterial pathogen with a broad range of hosts, including fish and mammals. In the present study, we used an advanced antibody array technology to identify the expression pattern of cytokines induced by $E$. tarda in a mouse infection model. In total, 31 and 24 differentially expressed cytokines (DECs) were identified in the plasma at $6 \mathrm{~h}$ and $24 \mathrm{~h}$ post-infection (hpi), respectively. The DECs were markedly enriched in the Gene Ontology (GO) terms associated with cell migration and response to chemokine and in the Kyoto Encyclopedia of Genes and Genomes (KEGG) pathways associated with immunity, diseases, and infection. Ten key DECs, including IL6 and TNF- $\alpha$, were found to form extensive protein-protein interaction networks. IL6 was demonstrated to inhibit $E$. tarda infection and be required for $E$. tarda-induced inflammatory response. TNF- $\alpha$ also exerted an inhibitory effect on E. tarda infection, and knockdown of fish (Japanese flounder) TNF- $\alpha$ promoted E. tarda invasion in host cells. Together, the results of this study revealed a comprehensive profile of cytokines induced by $E$. tarda, thus adding new insights into the role of cytokine-associated immunity against bacterial infection and also providing the potential plasma biomarkers of $E$. tarda infection for future studies.
\end{abstract}

Keywords: cytokine; Edwardsiella tarda; infection; antibody array; immune response

\section{Introduction}

Cytokines are small, soluble proteins produced by certain cells that act largely in a paracrine way to influence the activity of other cells [1]. Cytokine-mediated effects are critical to many biological processes, including inflammation, antimicrobial immunity, and cancer [2-5]. Cytokines are the most important class of mediators and can amplify and coordinate pro-inflammatory signals that lead to the expression of effector molecules, resulting in the modulation of diverse aspects of innate immunity against infection [6,7]. Currently, the term "cytokine" encompasses many types of proteins, including interleukins, chemokines, and the tumor necrosis factor (TNF) family. Interleukins mediate interactions between immune cells and are able to promote cell proliferation, differentiation, and functional activation [8-11]. Chemokines induce cell migration and activation by binding to specific G-protein-coupled cell surface receptors on target cells, such as neutrophils, monocytes, and lymphocytes, which play a pivotal role in host immune defense [12-14]. TNF- $\alpha$ is a factor with potent pro-inflammatory activity [15]. Members of the TNF family are involved in apoptosis, proliferation, invasion, and the immune response to infection [16,17].

Edwardsiella tarda is a Gram-negative bacterium and a pathogen to fish, reptiles, birds, amphibians, and mammals [18-20]. Several studies have indicated that E. tarda is able to replicate in fish and mammalian phagocytes and resist the killing of serum complements [21-25]. In addition, E. tarda has been reported to invade and replicate 
in epithelial cells such as HeLa, HEp-2, and flounder gill cells (FG-9307) [26-28]. The typical clinical signs caused by E. tarda infection include bacteremia and bloody colitis, suggesting a systemic spread of E. tarda from epithelium to tissues [29]. E. tarda infection is known to induce varied immune responses in different hosts. In zebrafish (Danio rerio), E. tarda infection upregulated the mRNA levels of interleukin (IL) $-1 \beta$ and TNF- $\alpha$ [20]. In Indian major carp (Labeo rohita), E. tarda challenge upregulated IL-1 $\beta$, inducible nitric oxide synthase (iNOS), complement component $\mathrm{C} 3$, and downregulated TNF- $\alpha$ [30]. In ginbuna crucian carp (Carassius auratus langsdorfii), E. tarda stimulated the innate immune response as well as the cytotoxic activity of cytotoxic T lymphocytes (CTLs) and increased the number of $\mathrm{CD}^{+}$cells, which contributed to the elimination of the bacteria from the tissues [31]. In Japanese flounder (Paralichthys olivaceus), E. tarda elicited a strong response of microRNAs (miRNAs) and their target genes, which in turn promoted/attenuated $E$. tarda invasion [32-35]. In mice, our previous work showed that living and non-living $E$. tarda induced strikingly different transcriptome profiles in macrophages, especially the genes associated with immunity [36].

Antibody array is a novel technology developed to meet the growing demand for multiplexed protein detection and can be applied to the simultaneous detection of multiple proteins [37]. In this study, in order to gain a new understanding of the role of cytokines in E. tarda infection, we employed an antibody array to examine systematically the plasma cytokine profiles of mice infected with E. tarda at different time points. We uncovered a large number of cytokines induced by $E$. tarda and investigated the antibacterial effects of some of the cytokines. In addition, we also applied the findings in mice to fish and examined the potential importance of fish cytokine to the defense against $E$. tarda infection.

\section{Materials and Methods}

\subsection{Animals and Cell Lines}

Clinically healthy BALB/c mice (female, 6-8 weeks, and $18 \pm 2 \mathrm{~g}$ ) were purchased from Qingdao Daren Fortune Animal Technology Co., Ltd. (Shandong, China) Before the experiment, mice were acclimatized in the laboratory for one week as reported previously [38]. RAW264.7 cells were purchased from American Tissue Culture Collection (ATCC, Rockville, MD, USA). The cells were cultured at $37^{\circ} \mathrm{C}$ in DMEM medium (Invitrogen, Carlsbad, CA, USA) supplemented with 10\% fetal bovine serum (FBS) (Gibco, Grand Island, NY, USA), 100 units $/ \mathrm{mL}$ penicillin, and $100 \mu \mathrm{g} / \mathrm{mL}$ streptomycin (Beyotime, Shanghai, China) in a humidified atmosphere containing $5 \% \mathrm{CO} 2$. The Japanese flounder cell line FG-9307 [39] was cultured at $24^{\circ} \mathrm{C}$ in L-15 medium (Sigma, St Louis, MO, USA) containing $10 \% \mathrm{FBS}, 100$ units $/ \mathrm{mL}$ penicillin, and $100 \mu \mathrm{g} / \mathrm{mL}$ streptomycin.

\subsection{In Vivo Infection}

The E. tarda strain used in this study was isolated from diseased fish [40]. E. tarda was inoculated (1:100) into Luria-Bertani (LB) medium $(5 \mathrm{~mL})$ and incubated at $28{ }^{\circ} \mathrm{C}$ to an $\mathrm{OD}_{600}$ of 0.8 . The bacteria were collected by centrifugation at $8000 \times g$ for $2 \mathrm{~min}$ at room temperature. The bacterial pellet was washed with PBS and resuspended in PBS to $5 \times 10^{8} \mathrm{CFU} / \mathrm{mL}$. In vivo infection was performed as reported previously [38] with a slight adjustment. Briefly, BALB/c mice (described above) were divided randomly into two groups and injected intraperitoneally (i.p.) with $100 \mu \mathrm{L}$ E. tarda suspension or PBS (control). At $6 \mathrm{~h}, 12 \mathrm{~h}$, and $24 \mathrm{~h}$ post-infection (hpi), blood, liver, and spleen were taken aseptically from the mice ( 3 animals/time point). The tissues were homogenized in PBS, and bacterial numbers in the homogenates were determined by plate count [38]. Blood collected from mice was placed in EDTA-K2 anticoagulant tube (KWS, Shijiazhuang, Hebei, China) and centrifuged at $2000 \times g$ to separate the plasma. 


\subsection{Antibody Array and Cytokine Determination}

The plasma collected above was used to detect cytokine profiles with the mouse cytokine array G1000 (RayBiotech, Norcross, GA, USA), which can simultaneously detect 96 separate cytokines, according to the instructions of the manufacturer. According to the internal positive control provided by RayBiotech, the signal values were read and normalized. Proteins with a fold change $\geq 1.5$ and adjusted $p$-value $<0.05$ were considered as significantly and differentially expressed cytokines (DECs).

\subsection{Functional Enrichment Analysis of the DECs}

Gene Ontology (GO) functional enrichment was performed using R/Bioconductor (http: / / www.bioconductor.org/, accessed on 17 May 2021). Kyoto Encyclopedia of Genes and Genomes (KEGG) pathway analysis was performed using the Kyoto Encyclopedia of Genes and Genomes database (https:/ / www.kegg.jp/kegg/rest/keggapi.html, accessed on 17 May 2021). After multiple test corrections, GO terms and KEGG pathways with adjusted $p$ values $<0.05$ were considered to be significantly enriched in DECs. Protein-protein interaction (PPI) networks were constructed with the DECs (Table 1) using STRING v10.0 (http:/ / string-db.org/, accessed on 17 May 2021) with default parameters. The STRING database provides a critical assessment and integration of protein-protein interactions, including direct (physical) as well as indirect (functional) associations [41]. In this study, PPI networks were constructed using STRING v10.0 with the minimum required interaction score set at a high confidence level (score: 0.700).

\subsection{Cellular Infection}

RAW264.7 cells were infected with E. tarda as described previously [42] with slight modification. Briefly, E. tarda was prepared as described above and resuspended in PBS to $1 \times 10^{8} \mathrm{CFU} / \mathrm{mL}$. E. tarda was added to RAW264.7 cells in a 24-well plate at a multiplicity of infection (MOI) of 5:1. The plate was centrifuged at $400 \times g$ for $10 \mathrm{~min}$, followed by incubation at $30^{\circ} \mathrm{C}$ for $1 \mathrm{~h}$. After incubation, the supernatant of the culture was removed. To kill extracellular E. tarda, fresh Opti-MEM (Gibco, Grand Island, NY, USA) containing gentamicin $(200 \mu \mathrm{g} / \mathrm{mL})$ (Solarbio, Beijing, China) was added to the plate, and the plate was incubated at $30{ }^{\circ} \mathrm{C}$ for $40 \mathrm{~min}$. The cells were then washed three times with PBS and cultured in Opti-MEM containing $30 \mu \mathrm{g} / \mathrm{mL}$ gentamicin for $0,2,4$, and $6 \mathrm{~h}$ to allow intracellular replication of the bacteria. At each time point, $300 \mu \mathrm{L} 1 \%$ Triton X-100 was added to the plate to lyse the cells. The lysate was diluted and plated onto LB agar plates supplemented with $30 \mu \mathrm{g} / \mathrm{mL}$ tetracycline (Solarbio, Beijing, China). The plates were incubated at $28{ }^{\circ} \mathrm{C}$ for $24-48 \mathrm{~h}$, and the number of colonies was counted. To examine the effect of cytokines on E. tarda infection, RAW 264.7 cells were treated with or without (control) $50 \mathrm{ng} / \mathrm{mL}$ recombinant IL6 (rIL6) (BioLegend, San Diego, CA, USA) for $2 \mathrm{~h}$, $200 \mathrm{ng} / \mathrm{mL}$ rTNF- $\alpha$ (BioLegend, San Diego, CA, USA), 100 ng/mL rCSF1 (Sino Biological, Beijing, China), or $200 \mathrm{ng} / \mathrm{mL}$ rIL12B (Sino Biological, Beijing, China) for $8 \mathrm{~h}$ prior to infection, and then infected with E. tarda as above. Flounder FG-9307 cells were infected with E. tarda as described previously [34] with a slight adjustment. E. tarda was added to FG-9307 cells in a 24-well plate at an MOI of 5:1. The plate was centrifuged at $400 \times$ $g$ for $10 \mathrm{~min}$, followed by incubation at $28^{\circ} \mathrm{C}$ for $1 \mathrm{~h}$. After incubation, the supernatant of the culture was removed. To kill extracellular E. tarda, fresh L-15 medium containing gentamicin $(200 \mu \mathrm{g} / \mathrm{mL})$ was added to the plate, and the plate was incubated at $28{ }^{\circ} \mathrm{C}$ for $40 \mathrm{~min}$. The cells were washed three times with PBS and cultured in L-15 medium containing $30 \mu \mathrm{g} / \mathrm{mL}$ gentamicin for $0,2,4$, and $6 \mathrm{~h}$. At each time point, the cells were lysed to determine the intracellular bacterial number as above. 


\subsection{Gene Knockdown by RNA Interference}

The siRNAs used in this study were synthesized by GenePharma (Shanghai, China). The sequences of the siRNAs are listed in Supplementary Materials Table S1. To interfere with IL6 expression, RAW264.7 cells were transfected with or without (control) IL6si or NCsi for $24 \mathrm{~h}$ using Lipofectamine RNAiMAX (Invitrogen, Carlsbad, CA, USA) according to the instructions of the manufacturer. To interfere with PoTNF- $\alpha$ expression, FG-9307 cells were transfected with or without (control) PoTNF- $\alpha$ si or NCsi as above. Gene knockdown was verified by quantitative real-time PCR (qRT-PCR) as described below and shown in Supplementary Material Figure S1. Infection of the gene knockdown cells with E. tarda was performed as described above.

\subsection{RNA Extraction and Quantitative Real-Time PCR ( $q R T-P C R)$}

To determine the expression of IL6 and PoTNF- $\alpha$ during E. tarda infection, RAW264.7 cells, and FG-9307 cells were infected with E. tarda as described above. To determine the effect of IL6 knockdown on inflammatory cytokine expression during E. tarda infection, RAW264.7 cells were pretreated with or without (control) IL6si or NCsi and then infected with E. tarda as described above. Total RNA of the infected cells was extracted with RNA-easy isolation reagent (Vazyme, Nanjing, China). The RNA was used for cDNA synthesis with First Strand cDNA Synthesis Kit (ToYoBo, Osaka, Japan) according to the manufacturer's protocol. qRT-PCR was carried out with Eppendorf Mastercycler epgradient S (Eppendorf, Hamburg, Germany) using TB Green Premix Ex Taq ${ }^{\mathrm{TM}}$ II (Takara, Dalian, China). The sequences of the primers used for qRT-PCR are listed in Supplementary Materials Table S2. The expression of each gene was normalized to that of glyceraldehyde-3phosphate dehydrogenase (GAPDH) (for mouse genes) or $\beta$-actin (for flounder genes) [43] and calculated using the comparative threshold cycle method $\left(2^{-\Delta \Delta C T}\right)$. The assay was performed in triplicate.

\subsection{Determination of Nitric Oxide (NO) Production}

RAW264.7 cells were pretreated with or without (control) IL6si or NCsi and then infected with $E$. tarda as described above. NO production was determined at 2, 4, and 6 hpi using the DAF-FM DA fluorescent probe (Beyotime, Beijing, China) according to the manufacturer's instructions. The experiment was performed three times.

\subsection{Statistical Analysis}

All experiments were performed three times. Statistical analyses were performed using student's $t$-tests and one-way analysis of variance (ANOVA) in GraphPad Prism version 6.01 (GraphPad Software Inc., San Diego, CA, USA). The results were considered statistically significant when $p<0.05$.

\section{Results}

\subsection{Detection of E. tarda-Induced Cytokines}

Following infection of mice, E. tarda disseminated into the liver, spleen, and blood in a time-dependent manner (Supplementary Materials Figure S2). E. tarda-induced production of 96 cytokines at 6 and 24 hpi was examined by antibody array (Figure 1A). Cytokines with a fold change $\geq 1.5$ and an adjusted $p$-value $<0.05$ were considered as differentially expressed cytokines (DECs). The expression levels and fold changes of the DECs are shown in Figure 1B and Table 1, respectively. At 6 hpi, 31 DECs were detected, 30 of which were upregulated. At $24 \mathrm{hpi}, 24 \mathrm{DECs}$ were detected, 22 of which were upregulated. Among the DECs, CCL5, CXCL1, IL6, CCL17, colony stimulating factor (CSF) 3, CXCL9, CCL20, CXCL13, TYRO3 protein tyrosine kinase (Tyro3), CCL12, tumor necrosis factor receptor superfamily member $1 \mathrm{~b}$ (sTNF RII), CCL22, CXCL16, tissue inhibitor of metalloproteinase 1 (TIMP1), IL1- $\alpha$, CCL11, and CD40 were upregulated at both $6 \mathrm{hpi}$ and $24 \mathrm{hpi}$; whereas, insulin-like growth factor 1 (IGF-I) was downregulated at both 6 hpi and $24 \mathrm{hpi}$. 


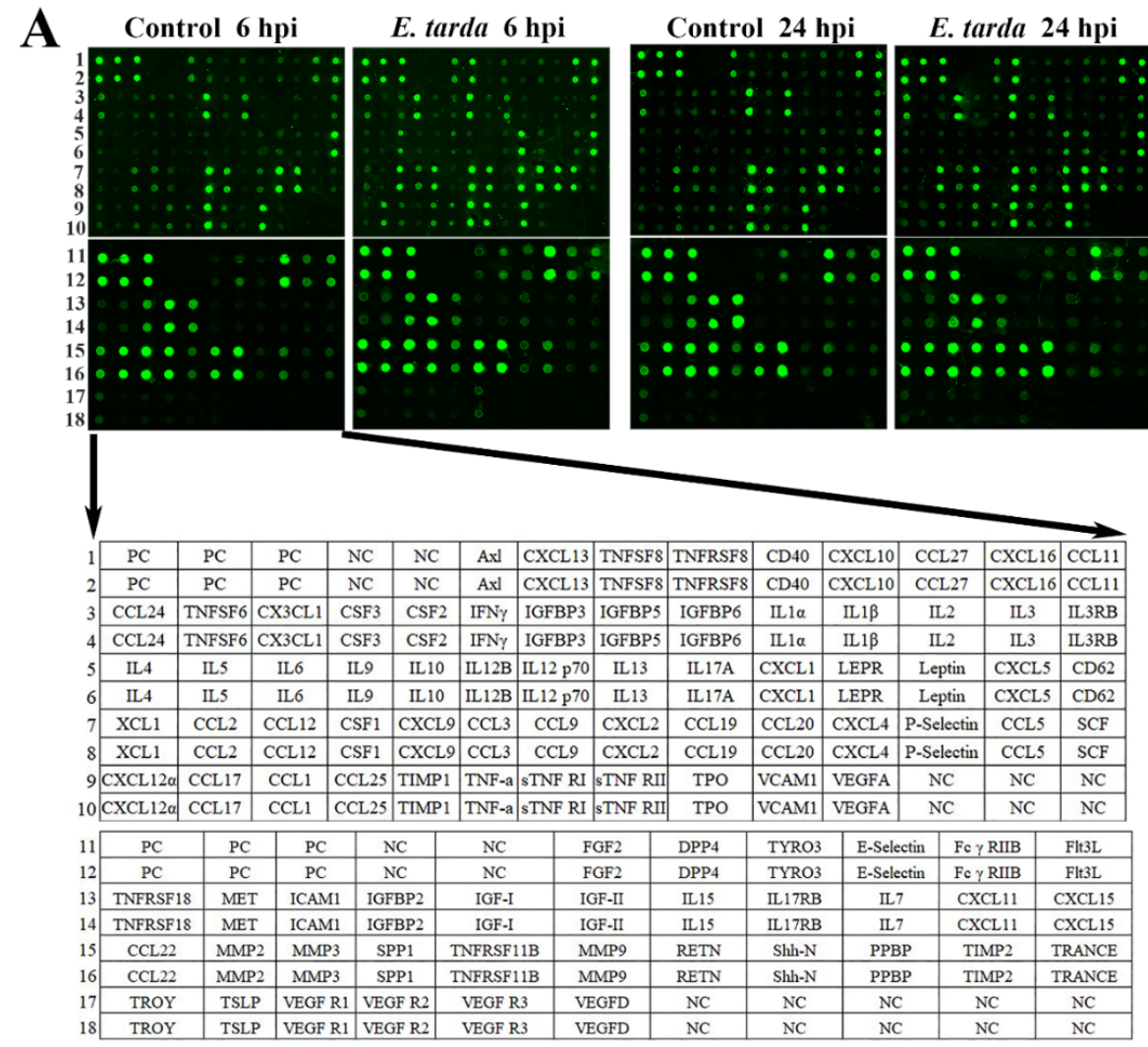

B

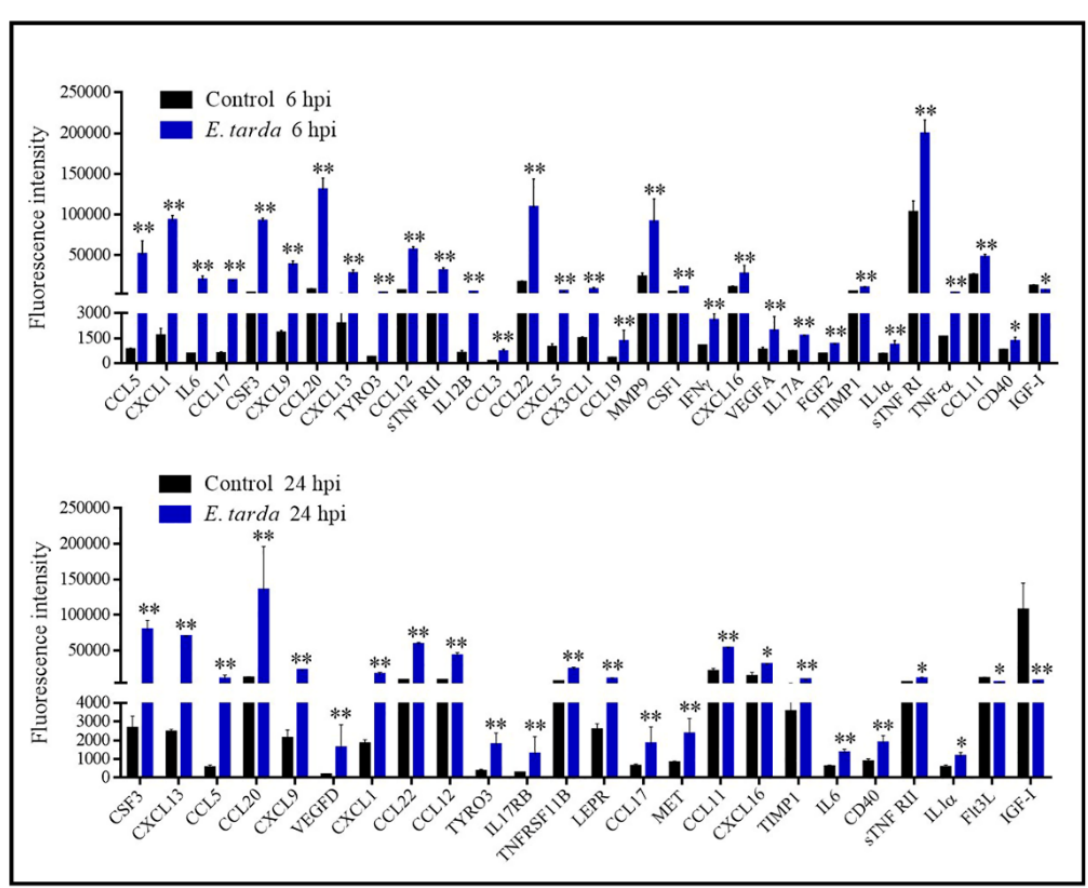

Figure 1. The cytokine expression profiles induced by Edwardsiella tarda. (A) Mice were infected with or without (control) E. tarda, and the expressions of 96 cytokines in the plasma at 6- or 24-hour post-infection (hpi) were detected by an antibody array (upper panel). Each cytokine was assayed in duplicate. The cytokine spots are indicated in the lower panel. PC, positive control; NC, negative control. The data shown are one representative of triplicate experiments. (B) Differentially expressed cytokines at 6 hpi (upper) and 24 hpi (lower) are shown in the histogram. Data are the means of triplicate assays and shown as mean $\pm \mathrm{SD} .{ }^{*} p<0.05 ;{ }^{* *} p<0.01$. 
Table 1. Fold change (infected/uninfected group) of the DECs at 6 and 24 h post-infection (hpi).

\begin{tabular}{|c|c|c|c|}
\hline \multirow[t]{2}{*}{ DEC } & \multirow[t]{2}{*}{ Description } & \multicolumn{2}{|c|}{ Fold Change } \\
\hline & & $6 \mathrm{hpi}$ & $24 \mathrm{hpi}$ \\
\hline CCL5 & Chemokine (C-C Motif) ligand 5 & 60.54 & 15.23 \\
\hline CXCL1 & Chemokine (C-X-C Motif) ligand 1 & 57.71 & 8.93 \\
\hline IL6 & Interleukin 6 & 35.08 & 2.34 \\
\hline CCL17 & Chemokine (C-C Motif) ligand 17 & 33.78 & 2.87 \\
\hline CSF3 & Colony-stimulating factor 3 & 29.23 & 30.23 \\
\hline CXCL9 & Chemokine (C-X-C Motif) ligand 9 & 20.98 & 10.69 \\
\hline CCL20 & Chemokine (C-C Motif) ligand 20 & 18.45 & 11.72 \\
\hline CXCL13 & Chemokine (C-X-C Motif) ligand 13 & 11.76 & 28.47 \\
\hline TYRO3 & TYRO3 protein tyrosine kinase 3 & 10.02 & 5.66 \\
\hline CCL12 & Chemokine (C-C Motif) ligand 12 & 9.27 & 5.81 \\
\hline sTNF RII & $\begin{array}{l}\text { Tumor necrosis factor receptor superfamily, } \\
\text { member } 1 \mathrm{~b}\end{array}$ & 8.35 & 2.17 \\
\hline IL12B & Interleukin $12 \mathrm{~b}$ & 7.84 & 0.64 \\
\hline CCL3 & Chemokine (C-C Motif) ligand 3 & 6.73 & 1.35 \\
\hline CCL22 & Chemokine (C-C Motif) ligand 22 & 6.39 & 7.69 \\
\hline CXCL5 & Chemokine $(C-X-C$ Motif) ligand 5 & 5.7 & 1.92 \\
\hline CX3CL1 & Chemokine (C-X3-C Motif) ligand 1 & 4.74 & 1.17 \\
\hline CCL19 & Chemokine (C-C Motif) ligand 19 & 4.22 & 1.46 \\
\hline MMP9 & Matrix metallopeptidase 9 & 3.85 & 1.33 \\
\hline CSF1 & Colony-stimulating factor 1 & 2.48 & 1.52 \\
\hline $\operatorname{IFN} \gamma$ & Interferon gamma & 2.46 & 1.02 \\
\hline CXCL16 & Chemokine (C-X-C Motif) ligand 16 & 2.45 & 2.47 \\
\hline VEGFA & Vascular endothelial growth factor-A & 2.34 & 1.44 \\
\hline IL17A & Interleukin $17 \mathrm{~A}$ & 2.32 & 1.3 \\
\hline FGF2 & Fibroblast growth factor 2 & 2.06 & 1.09 \\
\hline TIMP1 & Tissue inhibitor of metalloproteinase 1 & 2.06 & 2.38 \\
\hline $\operatorname{IL} 1 \alpha$ & Interleukin 1 alpha & 1.97 & 2.13 \\
\hline sTNF RI & $\begin{array}{l}\text { Tumor necrosis factor receptor superfamily, } \\
\text { member } 1 \mathrm{a}\end{array}$ & 1.95 & 1.37 \\
\hline TNF- $\alpha$ & Tumor necrosis factor & 1.92 & 1.69 \\
\hline CCL11 & Chemokine (C-C Motif) ligand 11 & 1.85 & 2.64 \\
\hline CD40 & CD40 Antigen & 1.68 & 2.19 \\
\hline IGF-I & Insulin-like growth factor 1 & 0.53 & 0.06 \\
\hline VEGFD & Vascular endothelial growth factor D & 1.2 & 9.95 \\
\hline IL17RB & Interleukin 17 receptor B & 1.38 & 4.45 \\
\hline TNFRSF11B & $\begin{array}{l}\text { Tumor necrosis factor receptor superfamily, } \\
\text { Member } 11 \mathrm{~b}\end{array}$ & 1.29 & 4.16 \\
\hline LEPR & Leptin receptor & 1.21 & 3.63 \\
\hline MET & Met proto-oncogene & 1.5 & 2.86 \\
\hline Flt3L & FMS-like tyrosine kinase 3 ligand & 1.28 & 0.42 \\
\hline
\end{tabular}

\subsection{GO and KEGG Analysis of the DECs}

DECs enriched in the top three GO functional terms are shown in Figure 2A. In the category of biological process, cytokines associated with granulocyte migration, leukocyte migration, and myeloid leukocyte migration were highly represented at $6 \mathrm{hpi}$, while cytokines of chemokine-mediated signaling pathway, neutrophil migration, and response to chemokine were highly represented at $24 \mathrm{hpi}$. In the category of molecular function, cytokine activity and receptor-ligand activity were highly represented at both 6 and $24 \mathrm{hpi}$; cytokine receptor binding and chemokine activity were highly enriched at 6 and $24 \mathrm{hpi}$, respectively. In the category of cellular components, receptor complex and varicosity were represented at both 6 and $24 \mathrm{hpi}$; collagen-containing extracellular matrix and main axon were represented at 6 and $24 \mathrm{hpi}$, respectively.

DECs of the top 10 most abundant KEGG pathways are shown in Figure 2B. Six of the 10 pathways were detected at both 6 and $24 \mathrm{hpi}$, including cytokine-cytokine receptor interaction, viral protein interaction with cytokine and cytokine receptor, chemokine signaling 
pathway, Rheumatoid arthritis, IL-17 signaling pathway, and TNF signaling pathway. Of the other pathways, chagas disease, influenza A, human cytomegalovirus infection, and toll-like receptor signaling pathway were highly represented at $6 \mathrm{hpi}$; pl3K-Akt signaling pathway, malaria, MAPK signaling pathway, and hematopoietic cell lineage were highly represented at $24 \mathrm{hpi}$.

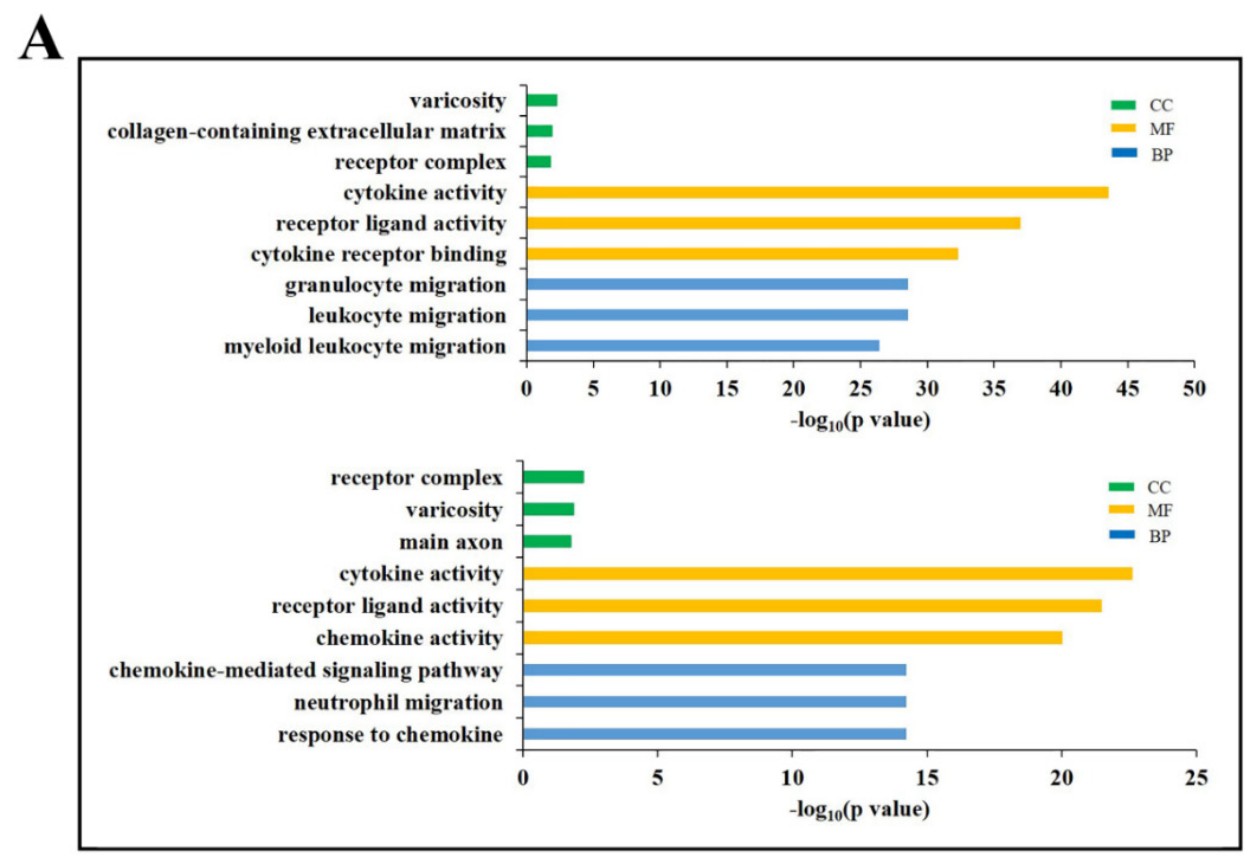

B

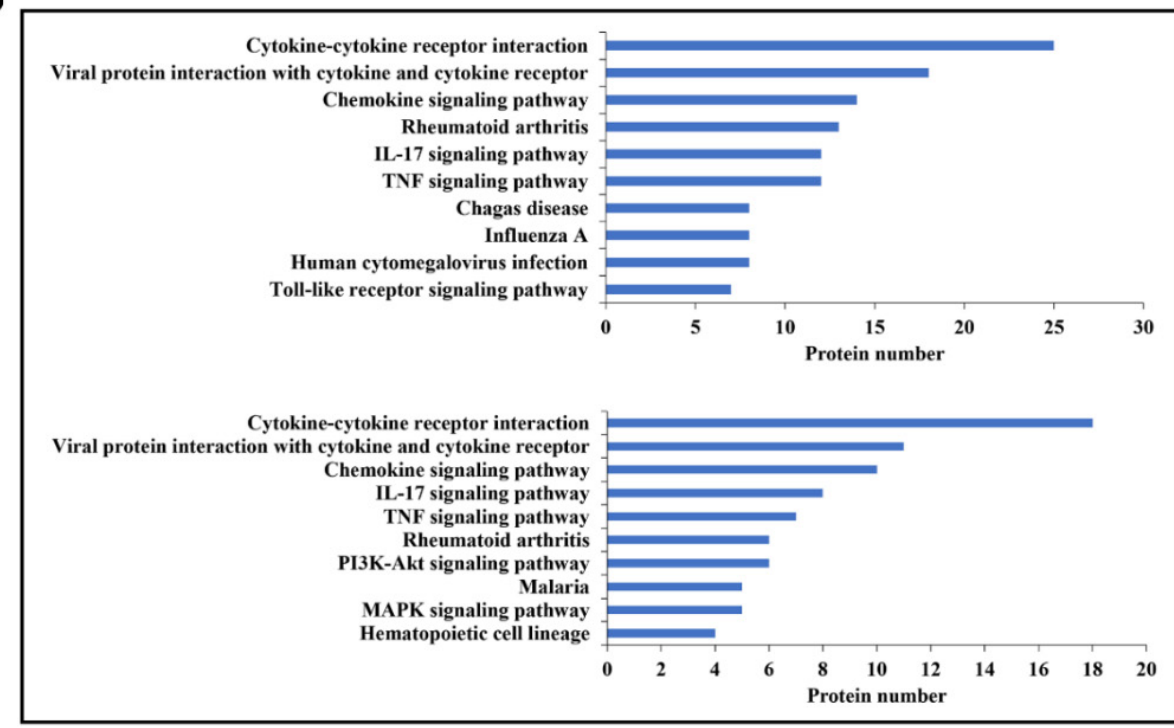

Figure 2. GO and KEGG enrichment of differentially expressed cytokines (DECs). (A) DECs of the top three significantly enriched GO terms at 6 (upper) and 24 (lower) hours post-infection (hpi). CC: Cellular Component, MF: Molecular Function, BP: Biological Process. (B) DECs of the top 10 significantly enriched KEGG pathways at 6 (upper) and 24 (lower) hpi.

\subsection{The Interaction Networks of the DECS}

Thirty-seven DECs (Table 1) constituted complicated interaction networks (Figure 3), in which multiple interactive relationships were formed among the DECs. Table 2 lists the top 10 key DECs with the highest numbers $(\geq 13)$ of protein-protein interactions. Of 
these cytokines, IL6 displayed the highest number (26) of interactions. Next to IL6 was TNF- $\alpha$, which interacted with 24 DECs. Other highly interactive DECs included CCL5, CXCL9, IL17, CXCL1, CXCL5, CCL3, CSF3, and VEGFA, with interaction numbers ranging between 13 and 19 (Table 2).

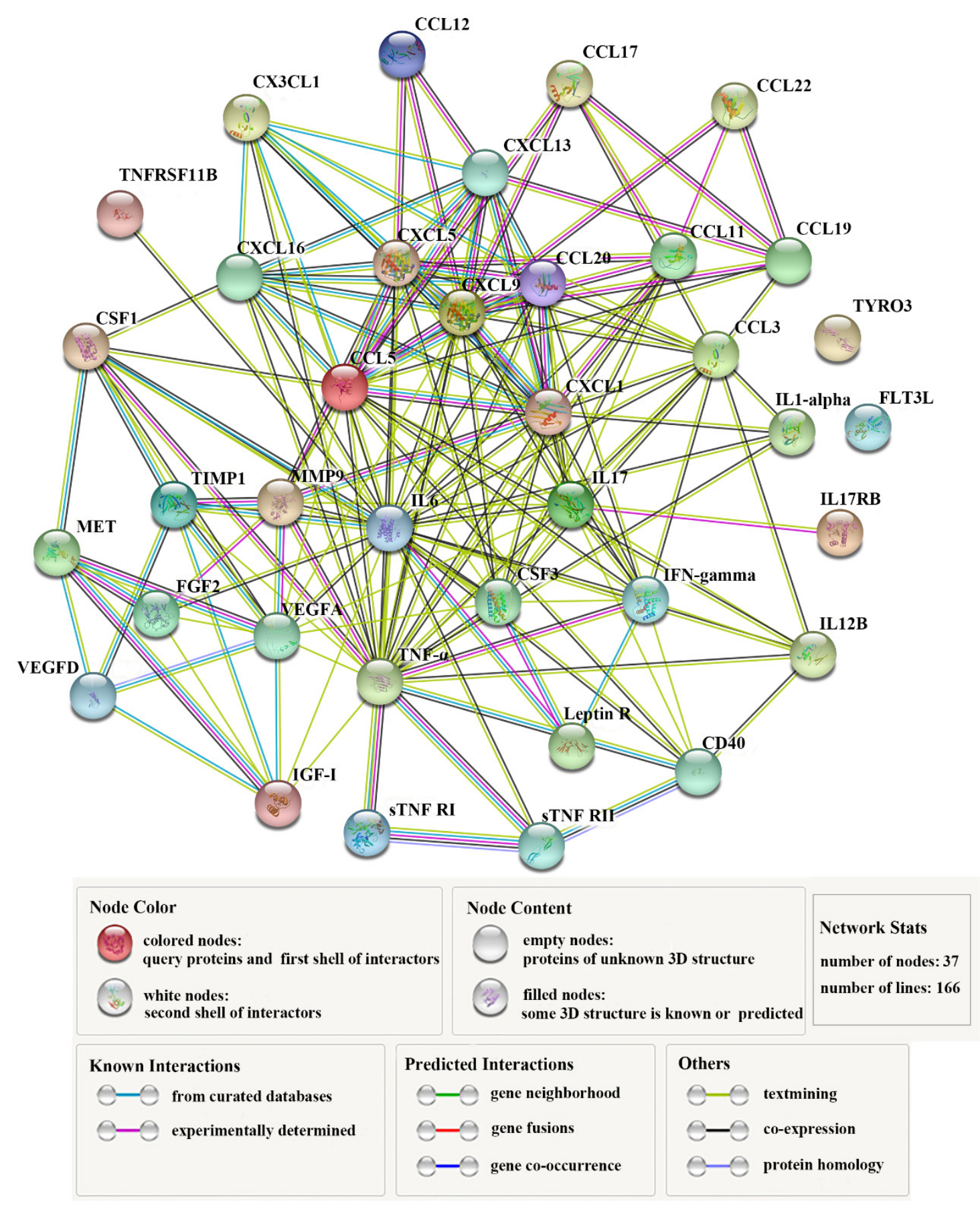

Figure 3. The interaction networks of differentially expressed cytokines (DECs). The networks formed by 37 DECs are shown. Nodes in the networks represent proteins; lines indicate association between the linked DECs. 
Table 2. Summary of the top 10 key differentially expressed cytokines (DECs) based on proteinprotein interaction analysis.

\begin{tabular}{ccc}
\hline DEC & Description & $\begin{array}{c}\text { Number of Protein-Protein } \\
\text { Interaction }\end{array}$ \\
\hline IL6 & Interleukin 6 & 26 \\
TNF- $\alpha$ & Tumor necrosis factor & 24 \\
CCL5 & Chemokine (C-C motif) ligand 5 & 19 \\
CXCL9 & Chemokine (C-X-C motif) ligand 9 & 19 \\
IL17A & Interleukin 17A & 17 \\
CXCL1 & Chemokine (C-X-C Motif) ligand 1 & 16 \\
CXCL5 & Chemokine (C-X-C Motif) ligand 5 & 15 \\
CCL3 & Chemokine (C-C Motif) ligand 3 & 14 \\
CSF3 & Colony stimulating factor 3 & 13 \\
VEGFA & Vascular endothelial growth factor-A & 13 \\
\hline
\end{tabular}

\subsection{Effects of the DECs on E. tarda Infection}

The effects of some of the key DECs on E. tarda infections in mouse macrophages (RAW264.7 cells) were examined. Pretreatment of the cells with rTNF- $\alpha$ and rIL6 significantly decreased the intracellular replication of E. tarda at 4 and $6 \mathrm{hpi}$, whereas pretreatment with rCSF1 had no significant effect on E. tarda infection (Figure 4A,B,D). The intracellular bacterial load in the cells treated with rIL12B was significantly higher than that in the control cells at 0 hpi but not at later time points (Figure 4C), suggesting that rIL12B likely affected the processes of bacterial attachment and invasion. During E. tarda infection, IL6 expression was found to increase significantly (Supplementary Materials Figure S3). Interference with IL6 expression markedly enhanced the intracellular infection of E. tarda (Figure 5A). IL6 knockdown significantly reduced the expression of TNF- $\alpha$, iNOS, and IL27 during E. tarda infection, but had no effect on the expression of IL10 (Figure 5B). IL6 knockdown also caused a significant inhibition of NO, but not ROS, production (Figure 5C and data not shown).

A

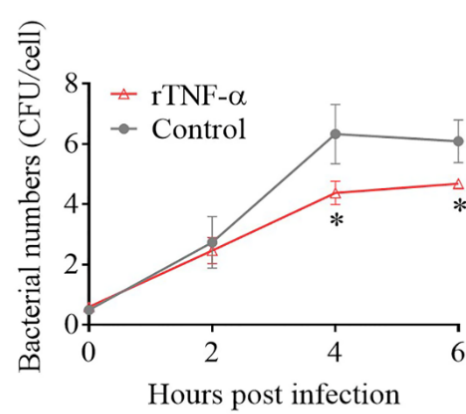

C

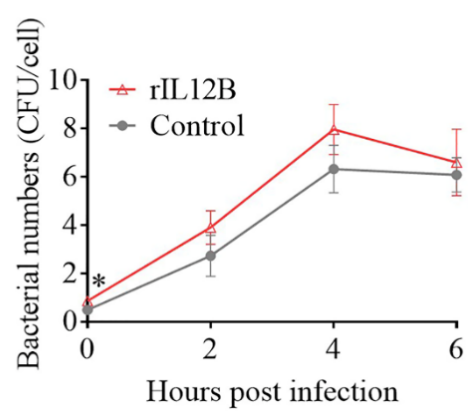

B

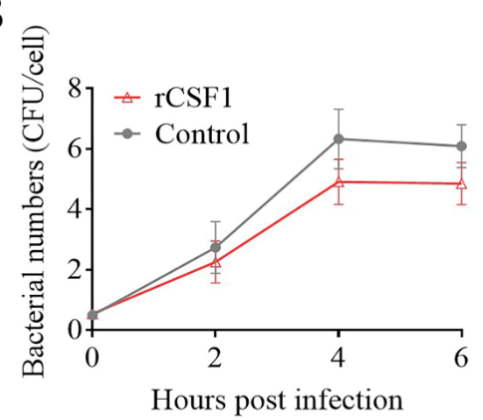

D

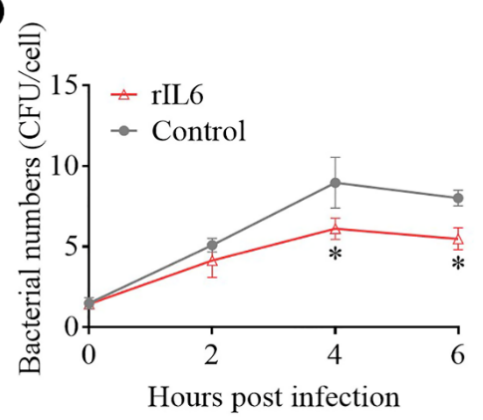

Figure 4. Effects of DECs on Edwardsiella tarda infection. RAW264.7 cells were pretreated with rTNF- $\alpha$ (A), rCSF1 (B), rIL12B (C), or rIL6 (D) and infected with E. tarda for $1 \mathrm{~h}$, and the extracellular bacteria were killed by antibiotic treatment. The cells were then incubated for various times. After incubation, the intracellular bacterial number (shown as colony forming units, CFU) was determined. Values are the means of triplicate experiments and shown as mean $\pm \mathrm{SD}$. ${ }^{*} p<0.05$. 
A

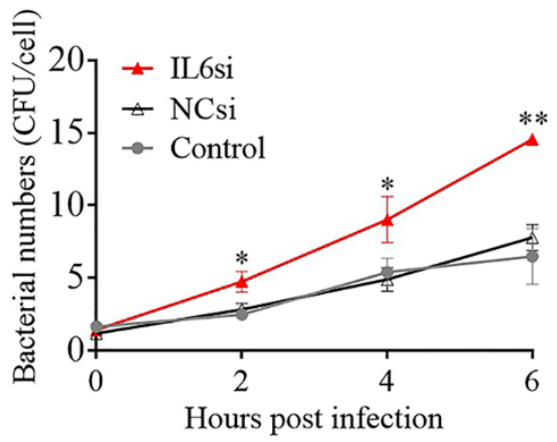

B

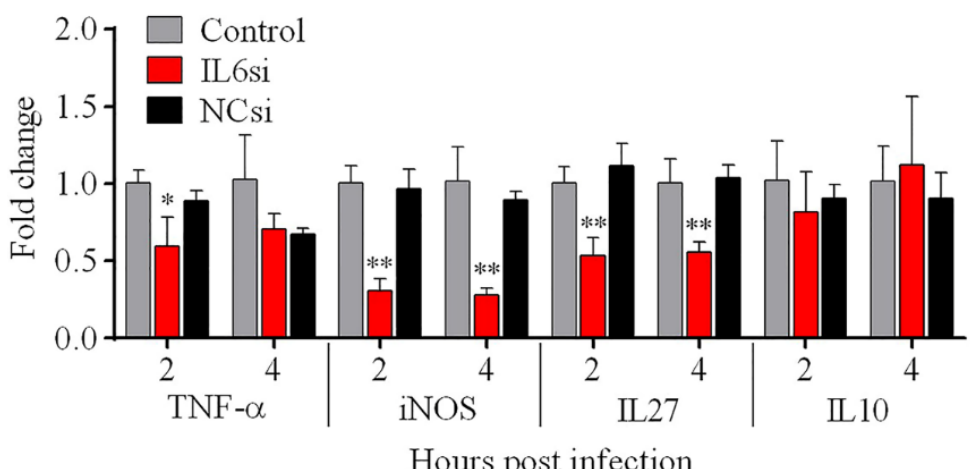

C

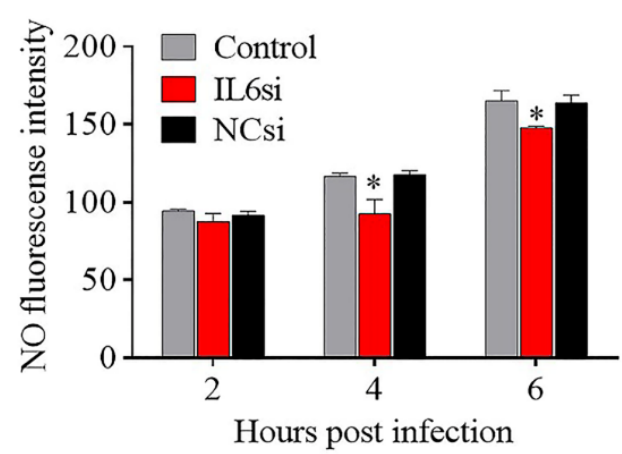

Figure 5. Effect of IL6 knockdown on Edwardsiella tarda infection and inflammatory cytokine expression. RAW264.7 cells treated with or without (control) IL6si (a siRNA targeting IL6) or NCsi (negative control siRNA) were infected with E. tarda for $1 \mathrm{~h}$, and the extracellular bacteria were killed by antibiotic treatment. The cells were then incubated for different hours. After incubation, the intracellular bacterial number (A), the expression of inflammatory genes (B), and nitric oxide (NO) production $(\mathrm{C})$ were determined. Values are the means of triplicate experiments and shown as mean \pm SD. ${ }^{*} p<0.05 ;{ }^{* *} p<0.01$.

\subsection{Effect of Japanese Flounder TNF- $\alpha$ (PoTNF- $\alpha)$ on E. tarda Infection}

Since, as shown above, TNF- $\alpha$ is a key DEC during E. tarda infection, we examined its involvement in E. tarda infection in Japanese flounder, an aquaculture fish highly susceptible to E. tarda. We found that the expression of PoTNF- $\alpha$ in flounder cells was significantly upregulated by E. tarda at 2 and $6 \mathrm{hpi}$ (Figure 6A). In flounder cells with PoTNF- $\alpha$ knockdown, the intracellular numbers of $E$. tarda were comparable to that of the control cells at 2 and 4 hpi but were significantly higher than that of the control cells at 6 hpi (Figure 6B). 
A

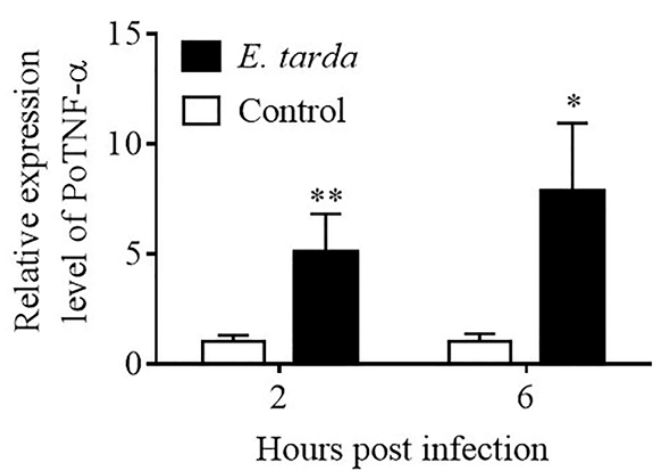

B

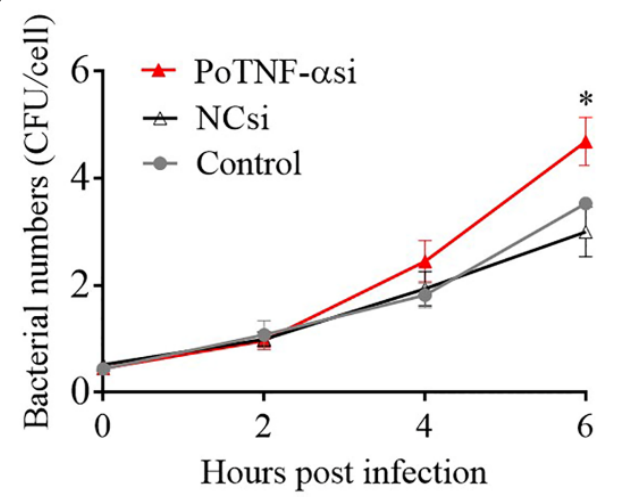

Figure 6. Effect of Japanese flounder TNF- $\alpha$ (PoTNF- $\alpha$ ) knockdown on Edwardsiella tarda infection. (A) Flounder FG-9307 cells were infected with $E$. tarda for $1 \mathrm{~h}$, and the extracellular bacteria were killed by antibiotic treatment. The cells were then incubated for 2 and $6 \mathrm{~h}$, and PoTNF- $\alpha$ expression was determined by qRT-PCR. (B) FG-9307 cells were pre-treated with or without (control) PoTNF- $\alpha$ si (a siRNA targeting PoTNF- $\alpha$ ) or NCsi (negative control siRNA) and infected with $E$. tarda for $1 \mathrm{~h}$. The extracellular bacteria were killed as above. The cells were then incubated for different hours, and the intracellular bacterial number was determined. Values are the means of triplicate experiments and shown as mean $\pm \mathrm{SD}$. ${ }^{*} p<0.05 ;{ }^{* *} p<0.01$.

\section{Discussion}

To date, little is known about the dynamics of host cytokine production induced by E. tarda infection. In this study, we utilized an antibody array to examine the cytokine response during E. tarda infection in mice at different time points. We detected 96 cytokines, 37 of which were DECs that exhibited significantly different expressions at 6 hpi and 24 hpi. The DECs enriched in the top GO, and KEGG terms/pathways were associated with cell migration and response to chemokine, immunity, disease, and infection, indicating an extensive induction of immune response by E. tarda. Furthermore, ten hub DECs with high levels of protein-protein interaction were identified, including CCL5, CXCL9, CXCL1, CXCL5, CCL3, IL6, and TNF- $\alpha$. The potential significance of these hub cytokines is discussed below.

Chemokines are a group of small molecules ( 8 to $12 \mathrm{kD})$ that induce chemotaxis in a variety of cells and are vital for the clearance of pathogens during immune surveillance [44]. In this study, CCL5 and CXCL1 were the most robustly upregulated chemokines, with a fold change of 60.54 and 57.71, respectively, at 6 hpi. As a pro-inflammatory chemokine, CCL5 is known to mediate the trafficking and homing of lymphoid cells such as monocytes and T-cells and also act on the other cells, including eosinophils, basophils, dendritic cells, natural killer cells, and mast cells $[45,46]$. A previous study showed that CCL5 expression increased over time during Mycobacterium tuberculosis infection, and CCL5knockout mice localized fewer antigen-presenting cells (APCs) and chemokine receptorpositive T-cells to the lungs in the early stage of $M$. $t b$ infection [47]. CCL5 also plays a key role in the immune response to viral infection [48-50]. It has been reported that plasma CCL5 was markedly elevated in COVID-19 patients [51]. CXCL1 is a secreted factor that functions as a neutrophil chemoattractant [52]. Neutrophil migration to the site of bacterial infection is a crucial step in host defense. In a murine model of intrapulmonary Streptococcus pneumoniae infection, CXCL1 was found to enhance neutrophil influx to control bacterial dissemination in the lungs, resulting in improved host survival [53]. Similarly, CXCL1-transgenic mice constitutively expressing lung CXCL1 showed elevated neutrophil recruitment and bacterial clearance in the lungs, as well as enhanced host survival after Klebsiella pneumoniae infection [54]. Given these reports, it is likely that during the E. tarda infection in our study, the dramatic increase of CCL5 and CXCL1 likely represents an immune mechanism of the host to combat the invading E. tarda. Other chemokines, 
including CXCL9, CXCL5, and CCL3, were also identified as the key DECs in our study. CXCL9 has been reported to possess antimicrobial activity against bacterial pathogens such as Citrobacter rodentium $[55,56]$. CXCL 5 was expressed by lung epithelial cells in response to $S$. pneumoniae infection and involved in neutrophil recruitment during inflammation response [57-59]. CCL3 has been shown to play a role in macrophage phagocytosis of $K$. pneumonia and is associated with the recruitment of leukocytes [60-62]. In our study, E. tarda infection significantly upregulated the expression of CXCL9, CXCL5, and CCL3, which may promote neutrophil recruitment and phagocytosis, resulting in enhanced bacterial clearance.

IL6 is a multifunctional cytokine involved in the regulation of acute-phase reaction, inflammatory response, and the transition from innate to adaptive immunity $[63,64]$. In our study, IL6 was the top DEC with extensive protein-protein interaction and was upregulated by E. tarda both in vivo and in vitro in macrophages. Previous studies have demonstrated that $E$. tarda is able to survive and replicate in host phagocytes, including macrophages $[23,42]$. In this study, we found that IL6 knockdown markedly increased the replication of $E$. tarda in macrophages, whereas the presence of rIL6 had the opposite effect, suggesting a requirement of IL6 in cellular defense against $E$. tarda invasion. A similar effect of IL6 has been observed in previous reports, which showed that mice with IL6 deficiency exhibited more severe Escherichia coli infections [65], and inhibition of IL6 signaling increased the survival of intracellular Brucella abortus in macrophages and decreased the production of TNF- $\alpha$ [66]. In our study, we observed that inhibition of IL6 significantly reduced iNOS, IL27, and TNF- $\alpha$ expression as well as NO production during E. tarda infection. iNOS is the major form of the enzyme that can generate NO, an important antimicrobial effector $[67,68]$. IL27 has a fundamental role in the regulation of innate and adaptive immunity and can be induced by IL6 during respiratory virus infection $[69,70]$. The enhanced E. tarda infection in RAW264.7 cells with IL6 knockdown observed in our study is likely due to the impaired ability of the cells to exert IL6-mediated inflammatory response.

$\mathrm{TNF}-\alpha$ is a key regulator of the host response to the microbial challenge by amplifying and coordinating pro-inflammatory signals [71,72]. Bacterial infection studies in mammalian models showed that TNF- $\alpha$ deficiency caused an increased bacterial burden in L. pneumophila infected mice [73], and inhibition of TNF- $\alpha$ reduced NO and ROS production and promoted the infection of Mycobacterium tuberculosis and Brucella abortus $[71,74,75]$. In fish, zebrafish TNF- $\alpha$ was involved in NF-kB expression [76]; Nile tilapia TNF- $\alpha$ responded to Streptococcus agalactiae infection and participated in apoptosis [77]; the recombinant protein of grass carp TNF- $\alpha$ could induce the phosphorylation of $\operatorname{IkB} \alpha$ [78]. In our study, TNF- $\alpha$ expression was found to be upregulated in E. tarda-infected mice, and rTNF- $\alpha$ treatment inhibited the intracellular replication of E. tarda in mouse macrophages, indicating an important role of TNF- $\alpha$ in the protective immunity against $E$. tarda. Since $E$. tarda is also a fish pathogen, we examined whether the findings in mice could be related to fish. Currently, no fish cell lines derived from macrophages or other phagocytes are available. In our study, we used the epithelial cells of Japanese flounder gill (FG-9307), which, like some mammalian epithelial cells, are known to be susceptible to E. tarda and have been used as a cellular model to study E. tarda infection $[28,79,80]$. We found that, similar to the observation in mice, TNF- $\alpha$ expression in flounder cells was upregulated by $E$. tarda, and that TNF- $\alpha$ knockdown significantly strengthened $E$. tarda infection in flounder cells, indicating that like mice, flounder also employed TNF- $\alpha$ in the regulation of immune defense against $E$. tarda. These results suggest a possible correlation between the immune responses of mice and fish caused by E. tarda infection.

In conclusion, in this study, we delineated the time-dependent plasma cytokine profile of mice during E. tarda infection. We identified 37 differentially expressed cytokines, including chemokines, interleukins, growth factors, and TNF superfamily members. Ten hub cytokines were further identified, which form complex interaction networks, and several of the hub cytokines were shown to be essential to effective $E$. tarda elimination. Our 
results add new insights into the importance of cytokines in mammal and fish immunity associated with bacterial infection and will serve as a foundation for future research on $E$. tarda infection and cytokine-mediated host immune defense.

Supplementary Materials: The following are available online at https:/ / www.mdpi.com/article/10 $.3390 /$ biom11081242/s1, Table S1. The sequences of the siRNAs used for gene knockdown; Table S2. List of primers used for qRT-PCR; Figure S1. Verification of mouse IL6 (A) and Japanese flounder PoTNF- $\alpha$ (B) knockdown; Figure S2. Edwardsiella tarda dissemination in mouse tissues; Figure S3. Expression of IL6 in Edwardsiella tarda-infected RAW264.7 cells.

Author Contributions: H.L. performed the experiments and wrote the first draft of the manuscript; H.L. and B.S. analyzed the data; S.J. designed the antibody array experiment; L.S. conceived the study and edited the manuscript. All authors have read and agreed to the published version of the manuscript.

Funding: This work was supported by the grants of the Marine S\&T Fund of Shandong Province for Pilot National Laboratory for Marine Science and Technology (Qingdao) (2018SDKJ0302-2), the National Key R\&D Program of China (2018YFD0900500), the Youth Innovation Promotion Association CAS (2021204), and the Taishan Scholar Program of Shandong Province.

Institutional Review Board Statement: The study was approved by the Ethics Committee of the Institute of Oceanology, Chinese Academy of Sciences (permit No. MB2007).

Informed Consent Statement: Not applicable.

Data Availability Statement: The data presented in this study are available in the article or Supplementary Materials.

Conflicts of Interest: The authors have no competing interests to declare.

\section{References}

1. Domingo-Gonzalez, R.; Prince, O.; Cooper, A.; Khader, S.A. Cytokines and Chemokines in Mycobacterium tuberculosis Infection. Microbiol. Spectr. 2016, 4, 37. [CrossRef] [PubMed]

2. Dinarello, C.A. Historical insights into cytokines. Eur. J. Immunol. 2007, 37, S34-S45. [CrossRef] [PubMed]

3. Xiao, X.; Zhu, W.; Zhang, Y.; Liao, Z.; Wu, C.; Yang, C.; Zhang, Y.; Xiao, S.; Su, J. Broad-Spectrum robust direct bactericidal activity of fish IFN Reveals an antimicrobial peptide-like function for Type I IFNs in vertebrates. J. Immunol. 2021, 206, 1337-1347. [CrossRef]

4. Kourko, O.; Seaver, K.; Odoardi, N.; Basta, S.; Gee, K. IL-27, IL-30, and IL-35: A cytokine triumvirate in cancer. Front. Oncol. 2019, 9, 969. [CrossRef]

5. Rieger, A.M.; Hanington, P.C.; Belosevic, M.; Barreda, D.R. Control of CSF-1 induced inflammation in teleost fish by a soluble form of the CSF-1 receptor. Fish. Shellfish Immunol. 2014, 41, 45-51. [CrossRef]

6. Mizgerd, J.P.; Spieker, M.R.; Doerschuk, C.M. Early response cytokines and innate immunity: Essential roles for TNF receptor 1 and type I IL-1 receptor during Escherichia coli pneumonia in mice. J. Immunol. 2001, 166, 4042-4048. [CrossRef]

7. Mehrad, B.; Standiford, T.J. Role of cytokines in pulmonary antimicrobial host defense. Immunol. Res. 1999, 20, 15-27. [CrossRef] [PubMed]

8. Mizel, S.B. The interleukins. FASEB J. 1989, 3, 2379-2388. [CrossRef]

9. Ouyang, W.; Rutz, S.; Crellin, N.K.; Valdez, P.A.; Hymowitz, S.G. Regulation and functions of the IL-10 family of cytokines in inflammation and disease. Annu. Rev. Immunol. 2011, 29, 71-109. [CrossRef]

10. Hunter, C.A.; Jones, S.A. IL-6 as a keystone cytokine in health and disease. Nat. Immunol. 2015, 16, 448-457. [CrossRef]

11. Zhou, X.J.; Xing, J.; Tang, X.Q.; Sheng, X.Z.; Chi, H.; Zhan, W.B. Interleukin-2 (IL-2) interacts with IL-2 receptor beta (IL-2R beta): Its potential to enhance the proliferation of CD4+T lymphocytes in flounder (Paralichthys olivaceus). Front. Immunol. 2020, 11, 14. [CrossRef]

12. Zlotnik, A.; Yoshie, O. Chemokines: A new classification system and their role in immunity. Immunity 2000, 12, 121-127. [CrossRef]

13. Luster, A.D. Chemokines-Chemotactic cytokines that mediate inflammation. N. Engl. J. Med. 1998, 338, 436-445. [CrossRef]

14. Zimmerman, K.A.; Hopp, K.; Mrug, M. Role of chemokines, innate and adaptive immunity. Cell. Signal. 2020, 73, 15. [CrossRef]

15. Blaser, H.; Dostert, C.; Mak, T.W.; Brenner, D. TNF and ROS Crosstal in Inflammation. Trends Cell Biol. 2016, 26, 249-261. [CrossRef] [PubMed]

16. Aggarwal, B.B.; Gupta, S.C.; Kim, J.H. Historical perspectives on tumor necrosis factor and its superfamily: 25 years later, a golden journey. Blood 2012, 119, 651-665. [CrossRef] 
17. Schneider, P.; MacKay, F.; Steiner, V.; Hofmann, K.; Bodmer, J.L.; Holler, N.; Ambrose, C.; Lawton, P.; Bixler, S.; Acha-Orbea, H.; et al. BAFF, a novel ligand of the tumor necrosis factor family, stimulates B cell growth. J. Exp. Med. 1999, 189, $1747-1756$. [CrossRef]

18. Leung, K.Y.; Siame, B.A.; Tenkink, B.J.; Noort, R.J.; Mok, Y.-K. Edwardsiella tarda-Virulence mechanisms of an emerging gastroenteritis pathogen. Microbes Infect. 2012, 14, 26-34. [CrossRef] [PubMed]

19. Park, S.B.; Aoki, T.; Jung, T.S. Pathogenesis of and strategies for preventing Edwardsiella tarda infection in fish. Vet. Res. 2012, 43, 11. [CrossRef] [PubMed]

20. Pressley, M.E.; Phelan, P.E.; Witten, P.E.; Mellon, M.T.; Kim, C.H. Pathogenesis and inflammatory response to Edwardsiella tarda infection in the zebrafish. Dev. Comp. Immunol. 2005, 29, 501-513. [CrossRef]

21. Ishibe, K.; Osatomi, K.; Hara, K.; Kanai, K.; Yamaguchi, K.; Oda, T. Comparison of the responses of peritoneal macrophages from Japanese flounder (Paralichthys olivaceus) against high virulent and low virulent strains of Edwardsiella tarda. Fish. Shellfish Immunol. 2008, 24, 243-251. [CrossRef]

22. Rao, P.S.S.; Lim, T.M.; Leung, K.Y. Opsonized virulent Edwardsiella tarda strains are able to adhere to and survive and replicate within fish phagocytes but fail to stimulate reactive oxygen intermediates. Infect. Immun. 2001, 69, 5689-5697. [CrossRef]

23. Zhang, L.; Ni, C.; Xu, W.; Dai, T.; Yang, D.; Wang, Q.; Zhang, Y.; Liu, Q. Intramacrophage Infection Reinforces the Virulence of Edwardsiella tarda. J. Bacteriol. 2016, 198, 1534-1542. [CrossRef] [PubMed]

24. Li, M.-f.; Sun, L. Edwardsiella tarda Sip2: A Serum-Induced Protein That Is Essential to Serum Survival, Acid Resistance, Intracellular Replication, and Host Infection. Front. Microbiol. 2018, 9, 1084. [CrossRef]

25. Li, M.-f.; Sun, L.; Li, J. Edwardsiella tarda evades serum killing by preventing complement activation via the alternative pathway. Fish. Shellfish Immunol. 2015, 43, 325-329. [CrossRef] [PubMed]

26. Marques, L.R.M.; Toledo, M.R.F.; Silva, N.P.; Magalhaes, M.; Trabulsi, L.R. Invasion of hela-cells by Edwardsiella-tarda. Curr. Microbiol. 1984, 10, 129-132. [CrossRef]

27. Strauss, E.J.; Ghori, N.; Falkow, S. An Edwardsiella tarda strain containing a mutation in a gene with homology to shlB and hpmB is defective for entry into epithelial cells in culture. Infect. Immun. 1997, 65, 3924-3932. [CrossRef]

28. Wang, B.; Yu, T.; Dong, X.; Zhang, Z.; Song, L.; Xu, Y.; Zhang, X.-H. Edwardsiella tarda invasion of fish cell lines and the activation of divergent cell death pathways. Vet. Microbiol. 2013, 163, 282-289. [CrossRef]

29. Okuda, J.; Kiriyama, M.; Yamanoi, E.; Nakai, T. The type III secretion system-dependent repression of NF-kappa B activation to the intracellular growth of Edwardsiella tarda in human epithelial cells. FEMS Microbiol. Lett. 2008, 283, 9-14. [CrossRef]

30. Mohanty, B.R.; Sahoo, P.K. Immune responses and expression profiles of some immune-related genes in Indian major carp, Labeo rohita to Edwardsiella tarda infection. Fish. Shellfish Immunol. 2010, 28, 613-621. [CrossRef] [PubMed]

31. Yamasaki, M.; Araki, K.; Nakanishi, T.; Nakayasu, C.; Yoshiura, Y.; Iida, T.; Yamamoto, A. Adaptive immune response to Edwardsiella tarda infection in ginbuna crucian carp, Carassius auratus langsdorfii. Vet. Immunol. Immunopathol. 2013, 153, 83-90. [CrossRef] [PubMed]

32. Li, W.; Hu, Y.-h.; Jiang, S.; Sun, L. Global profiling and characterization of Japanese flounder (Paralichthys olivaceus) kidney microRNAs regulated by Edwardsiella tarda infection in a time-dependent fashion. Fish. Shellfish Immunol. 2019, 93, 766-780. [CrossRef]

33. Li, W.; Guan, X.; Sun, L. Phosphatase and tensin homolog (PTEN) of Japanese flounder-its regulation by miRNA and role in autophagy, apoptosis and pathogen Infection. Int. J. Mol. Sci. 2020, 21, 7725. [CrossRef]

34. Li, W.; Guan, X.-1.; Jiang, S.; Sun, L. The novel fish miRNA pol-miR-novel_171 and its target gene FAM49B play a critical role in apoptosis and bacterial infection. Dev. Comp. Immunol. 2020, 106, 103616. [CrossRef] [PubMed]

35. Guan, X.-1.; Zhang, B.-c.; Sun, L. pol-miR-194a of Japanese flounder (Paralichthys olivaceus) suppresses type I interferon response and facilitates Edwardsiella tarda infection. Fish. Shellfish Immunol. 2019, 87, 220-225. [CrossRef] [PubMed]

36. Li, H.; Sun, B.; Ning, X.; Jiang, S.; Sun, L. A Comparative Analysis of Edwardsiella tarda-induced transcriptome profiles in RAW264.7 cells reveals new insights into the strategy of bacterial immune evasion. Int. J. Mol. Sci. 2019, 20, 5724. [CrossRef]

37. Kibat, J.; Schirrmann, T.; Knape, M.J.; Helmsing, S.; Meier, D.; Hust, M.; Schroeder, C.; Bertinetti, D.; Winter, G.; Pardes, K.; et al. Utilisation of antibody microarrays for the selection of specific and informative antibodies from recombinant library binders of unknown quality. N. Biotechnol. 2016, 33, 574-581. [CrossRef]

38. Gu, H.-J.; Sun, Q.-L.; Luo, J.-C.; Zhang, J.; Sun, L. A First Study of the Virulence Potential of a Bacillus subtilis Isolate from Deep-Sea Hydrothermal Vent. Front. Cell. Infect. Microbiol. 2019, 9, 183. [CrossRef]

39. Tong, S.L.; Li, H.; Miao, H.Z. The establishment and partial characterization of a continuous fish cell line FG-9307 from the gill of flounder Paralichthys olivaceus. Aquaculture 1997, 156, 327-333. [CrossRef]

40. Zhang, M.; Sun, K.; Sun, L. Regulation of autoinducer 2 production and luxS expression in a pathogenic Edwardsiella tarda strain. Microbiology 2008, 154, 2060-2069. [CrossRef] [PubMed]

41. Szklarczyk, D.; Franceschini, A.; Wyder, S.; Forslund, K.; Heller, D.; Huerta-Cepas, J.; Simonovic, M.; Roth, A.; Santos, A.; Tsafou, K.P.; et al. STRING v10: Protein-protein interaction networks, integrated over the tree of life. Nucleic Acids Res. 2015, 43, D447-D452. [CrossRef] [PubMed]

42. Sui, Z.-h.; Xu, H.; Wang, H.; Jiang, S.; Chi, H.; Sun, L. Intracellular Trafficking Pathways of Edwardsiella tarda: From Clathrin- and Caveolin-Mediated Endocytosis to Endosome and Lysosome. Front. Cell. Infect. Microbiol. 2017, 7, 400. [CrossRef] [PubMed] 
43. Zheng, W.-j.; Sun, L. Evaluation of housekeeping genes as references for quantitative real time RT-PCR analysis of gene expression in Japanese flounder (Paralichthys olivaceus). Fish. Shellfish Immunol. 2011, 30, 638-645. [CrossRef] [PubMed]

44. Borish, L.C.; Steinke, J.W. 2. Cytokines and chemokines. J. Allergy Clin. Immunol. 2003, 111 (Suppl. 2), S460-S475. [CrossRef]

45. Appay, V.; Rowland-Jones, S.L. RANTES: A versatile and controversial chemokine. Trends Immunol. 2001, 22, 83-87. [CrossRef]

46. Schall, T.J. Biology of the RANTES/SIS cytokine family. Cytokine 1991, 3, 165-183. [CrossRef]

47. Vesosky, B.; Rottinghaus, E.K.; Stromberg, P.; Turner, J.; Beamer, G. CCL5 participates in early protection against Mycobacterium tuberculosis. J. Leukoc. Biol. 2010, 87, 1153-1165. [CrossRef]

48. Salimi, V.; Ramezani, A.; Mirzaei, H.; Tahamtan, A.; Faghihloo, E.; Rezaei, F.; Naseri, M.; Bont, L.; Mokhtari-Azad, T.; TavakoliYaraki, M. Evaluation of the expression level of 12/15 lipoxygenase and the related inflammatory factors (CCL5, CCL3) in respiratory syncytial virus infection in mice model. Microb. Pathog. 2017, 109, 209-213. [CrossRef]

49. Matikainen, S.; Pirhonen, J.; Miettinen, M.; Lehtonen, A.; Govenius-Vintola, C.; Sareneva, T.; Julkunen, I. Influenza A and Sendai viruses induce differential chemokine gene expression and transcription factor activation in human macrophages. Virology 2000, 276, 138-147. [CrossRef] [PubMed]

50. Nischalke, H.D.; Nattermann, J.; Fischer, H.P.; Sauerbruch, T.; Spengler, U.; Dumoulin, F.L. Semiquantitative analysis of intrahepatic CC-chemokine mRNAs in chronic hepatitis C. Mediat. Inflamm. 2004, 13, 357-359. [CrossRef]

51. Patterson, B.K.; Seethamraju, H.; Dhody, K.; Corley, M.J.; Kazempour, K.; Lalezari, J.P.; Pang, A.P.; Sugai, C.; Francisco, E.B.; Pise, A.; et al. Disruption of the CCL5/RANTES-CCR5 pathway restores immune homeostasis and reduces plasma viral load in critical COVID-19. MedRxiv. Preprint. 2020, 5, 20084673.

52. Liu, X.-F.; Wu, J.; Wang, M.-Y.; Chen, Y.-J.; Cao, Y.; Hu, C.-J. Identification of novel inflammatory cytokines and contribution of keratinocyte-derived chemokine to inflammation in response to vibrio vulnificus infection in mice. Inflammation 2015, 38, 1864-1873. [CrossRef] [PubMed]

53. Paudel, S.; Baral, P.; Ghimire, L.; Bergeron, S.; Jin, L.; DeCorte, J.A.; Le, J.T.; Cai, S.; Jeyaseelan, S. CXCL1 regulates neutrophil homeostasis in pneumonia-derived sepsis caused by Streptococcus pneumoniae serotype 3. Blood 2019, 133, 1335-1345. [CrossRef]

54. Tsai, W.C.; Strieter, R.M.; Wilkowski, J.M.; Bucknell, K.A.; Burdick, M.D.; Lira, S.A.; Standiford, T.J. Lung-specific transgenic expression of KC enhances resistance to Klebsiella pneumoniae in mice. J. Immunol. 1998, 161, 2435-2440. [PubMed]

55. Egesten, A.; Eliasson, M.; Johansson, H.M.; Olin, A.I.; Morgelin, M.; Mueller, A.; Pease, J.E.; Frick, I.M.; Bjorck, L. The CXC chemokine MIG/CXCL9 is important in innate immunity against Streptococcus pyogenes. J. Infect. Dis. 2007, 195, 684-693. [CrossRef]

56. Reid-Yu, S.A.; Tuinema, B.R.; Small, C.N.; Xing, L.; Coombes, B.K. CXCL9 contributes to antimicrobial protection of the gut during Citrobacter rodentium infection independent of chemokine-receptor signaling. PLoS Pathog. 2015, 11, e1004648. [CrossRef]

57. Santos, I.; Colaco, H.G.; Neves-Costaa, A.; Seixas, E.; Velho, T.R.; Pedroso, D.; Barros, A.; Martins, R.; Carvalho, N.; Payen, D.; et al. CXCL5-mediated recruitment of neutrophils into the peritoneal cavity of Gdf15-deficient mice protects against abdominal sepsis. Proc. Natl. Acad. Sci. USA 2020, 117, 12281-12287. [CrossRef]

58. Yamamoto, K.; Ahyi, A.N.N.; Pepper-Cunningham, Z.A.; Ferrari, J.D.; Wilson, A.A.; Jones, M.R.; Quinton, L.J.; Mizgerd, J.P. Roles of lung epithelium in neutrophil recruitment during pneumococcal pneumonia. Am. J. Respir. Cell Mol. Biol. 2014, 50, $253-262$. [CrossRef]

59. Mei, J.; Liu, Y.; Dai, N.; Favara, M.; Greene, T.; Jeyaseelan, S.; Poncz, M.; Lee, J.S.; Worthen, G.S. CXCL5 regulates chemokine scavenging and pulmonary host defense to bacterial infection. Immunity 2010, 33, 106-117. [CrossRef] [PubMed]

60. Maurer, M.; von Stebut, E. Macrophage inflammatory protein-1. Int. J. Biochem. Cell Biol. 2004, 36, 1882-1886. [CrossRef]

61. Aust, V.; Kress, E.; Abraham, S.; Schroeder, N.; Kipp, M.; Stope, M.B.; Pufe, T.; Tauber, S.C.; Brandenburg, L.-O. Lack of chemokine (C-C motif) ligand 3 leads to decreased survival and reduced immune response after bacterial meningitis. Cytokine 2018, 111, 246-254. [CrossRef] [PubMed]

62. Lindell, D.M.; Standiford, T.J.; Mancuso, P.; Leshen, Z.J.; Huffnagle, G.B. Macrophage inflammatory protein 1 alpha CCL3 is required for clearance of an acute Klebsiella pneumoniae pulmonary infection. Infect. Immun. 2001, 69, 6364-6369. [CrossRef] [PubMed]

63. Fielding, C.A.; McLoughlin, R.M.; McLeod, L.; Colmont, C.S.; Najdovska, M.; Grail, D.; Ernst, M.; Jones, S.A.; Topley, N.; Jenkins, B.J. IL-6 regulates neutrophil trafficking during acute inflammation via STAT3. J. Immunol. 2008, 181, 2189-2195. [CrossRef] [PubMed]

64. Jones, S.A. Directing transition from innate to acquired immunity defining a role for IL-6. J. Immunol. 2005, 175, 3463-3468. [CrossRef]

65. Dalrymple, S.A.; Slattery, R.; Aud, D.M.; Krishna, M.; Lucian, L.A.; Murray, R. Interleukin-6 is required for a protective immune response to systemic Escherichia coli infection. Infect. Immun. 1996, 64, 3231-3235. [CrossRef]

66. Huynh Tan, H.; Tran Xuan Ngoc, H.; Reyes, A.W.B.; Arayan, L.T.; Vu, S.H.; Min, W.; Lee, H.J.; Kang, C.K.; Kim, D.H.; Tark, D.S.; et al. Interleukin 6 promotes Brucella abortus clearance by controlling bactericidal activity of macrophages and CD8(+) T cell differentiation. Infect. Immun. 2019, 87, e00431-19.

67. Chakravortty, D.; Hensel, M. Inducible nitric oxide synthase and control of intracellular bacterial pathogens. Microbes Infect. 2003, 5, 621-627. [CrossRef]

68. Eriksson, S.; Bjorkman, J.; Borg, S.; Syk, A.; Pettersson, S.; Andersson, D.I.; Rhen, M. Salmonella typhimurium mutants that downregulate phagocyte nitric oxide production. Cell. Microbiol. 2000, 2, 239-250. [CrossRef] 
69. Petes, C.; Odoardi, N.; Plater, S.M.; Martin, N.L.; Gee, K. IL-27 amplifies cytokine responses to Gram-negative bacterial products and Salmonella typhimurium infection. Sci. Rep. 2018, 8, 1-13. [CrossRef]

70. Pyle, C.J.; Uwadiae, F.I.; Swieboda, D.P.; Harker, J.A. Early IL-6 signalling promotes IL-27 dependent maturation of regulatory T cells in the lungs and resolution of viral immunopathology. PLoS Pathog. 2017, 13, e1006640. [CrossRef]

71. Hop, H.T.; Reyes, A.W.B.; Huy, T.X.N.; Arayan, L.T.; Min, W.; Lee, H.J.; Rhee, M.H.; Chang, H.H.; Kim, S. Activation of nf-kbmediated tnf-induced antimicrobial immunity is required for the efficient brucella abortus clearance in RAW 264.7 cells. Front. Cell. Infect. Microbiol. 2017, 7, 437. [CrossRef]

72. Liew, F.Y.; Li, Y.; Millott, S. Tumor-necrosis-factor-alpha synergizes with IFN-gamma in mediating killing of leishmania-major through the induction of Nitric-oxide. J. Immunol. 1990, 145, 4306-4310. [PubMed]

73. Ziltener, P.; Reinheckel, T.; Oxenius, A. Neutrophil and alveolar macrophage-mediated innate immune control of legionella pneumophila lung infection via TNF and ROS. PLoS Pathog. 2016, 12, e1005591. [CrossRef]

74. Lynch, K.; Farrell, M. Cerebral tuberculoma in a patient receiving anti-TNF alpha (adalimumab) treatment. Clin. Rheumatol. 2010, 29, 1201-1204. [CrossRef] [PubMed]

75. Seong, S.-S.; Choi, C.-B.; Woo, J.-H.; Bae, K.W.; Joung, C.-L.; Uhm, W.-S.; Kim, T.-H.; Jun, J.-B.; Yoo, D.-H.; Lee, J.-T.; et al. Incidence of tuberculosis in Korean patients with rheumatoid arthritis (RA): Effects of RA itself and of tumor necrosis factor blockers. J. Rheumatol. 2007, 34, 706-711.

76. Wang, W.-L.; Liu, W.; Gong, H.-Y.; Hong, J.-R.; Lin, C.-C.; Wu, J.-L. Activation of cytokine expression occurs through the TNF alpha/NF-kappa B-mediated pathway in birnavirus-infected cells. Fish. Shellfish Immunol. 2011, 31, 10-21. [CrossRef]

77. Li, K.; Qiu, H.; Yan, J.; Shen, X.; Wei, X.; Duan, M.; Yang, J. The involvement of TNF-alpha and TNF-beta as proinflammatory cytokines in lymphocyte-mediated adaptive immunity of Nile tilapia by initiating apoptosis. Dev. Comp. Immunol. 2021, 115, 103884. [CrossRef]

78. Zhang, A.; Chen, D.; Wei, H.; Du, L.; Zhao, T.; Wang, X.; Zhou, H. Functional characterization of TNF-alpha in grass carp head kidney leukocytes: Induction and involvement in the regulation of NF-kappa B signaling. Fish. Shellfish Immunol. 2012, 33, 1123-1132. [CrossRef] [PubMed]

79. Liu, J.; Cao, D.; Liu, Y.; Li, Z.; Si, Y.; Wang, Z.; Zhang, Q.; Yu, H.; Wang, X. Expression and functional analysis of receptorinteracting serine/threonine kinase 2 (RIP2) in Japanese flounder (Paralichthys olivaceus). Fish. Shellfish Immunol 2018, 75, 327-335. [CrossRef] [PubMed]

80. Ma, D.; Gu, H.; Shi, Y.; Huang, H.; Sun, D.; Hu, Y. Edwardsiella piscicida YefM-YoeB: A type II toxin-antitoxin system that is related to antibiotic resistance, biofilm formation, serum survival, and host infection. Front. Microbiol 2021, 12, 646299. [CrossRef] 